Article

\title{
Screening for Elevated Blood Lead Levels and Related Risk Factors among Thai Children Residing in a Fishing Community
}

\author{
Supabhorn Yimthiang ${ }^{1, * \mathbb{C}}$, Donrawee Waeyang ${ }^{1}$ and Saruda Kuraeiad ${ }^{2} \mathbb{C}$ \\ 1 School of Public Health, Walailak University, Thaiburi, Thasala, Nakhon Si Thammarat 80160, Thailand; \\ donrawee.wae@gmail.com \\ 2 School of Allied Health Sciences, Walailak University, Thaiburi, Thasala, Nakhon Si Thammarat 80160, \\ Thailand; ksaruda@gmail.com \\ * Correspondence: ksupapor@mail.wu.ac.th; Tel.: +66-84852-5559
}

Received: 17 August 2019; Accepted: 8 October 2019; Published: 12 October 2019

\begin{abstract}
The present study explored environmental and behavioral factors associated with elevated blood lead (Pb) levels in 311 children (151 girls and 160 boys), aged 3-7 years, who lived in a coastal fishing community of the Pakpoon Municipality, Nakhon Si Thammarat, Thailand. The geometric mean for blood $\mathrm{Pb}$ was $2.81 \mu \mathrm{g} / \mathrm{dL}$, ranging between 0.03 and $26.40 \mu \mathrm{g} / \mathrm{dL}$. The percentage of high blood $\mathrm{Pb}$ levels, defined as blood $\mathrm{Pb} \geq 5 \mu \mathrm{g} / \mathrm{dL}$, was $10.0 \%$ in boys and $13.9 \%$ in girls. Parental occupation in producing fishing nets with lead weights was associated with a marked increase in the prevalence odds ratio (POR) for high blood Pb (POR 17.54, 95\%; CI: 7.093, 43.390; $p<0.001$ ), while milk consumption was associated with $61 \%$ reduction in the POR for high blood $\mathrm{Pb}$ (POR 0.393, 95\%; CI: $0.166,0.931 ; p=0.034)$. High blood $\mathrm{Pb}$ was associated with an increased risk for abnormal growth (POR 2.042, 95\%; CI: 0.999, 4.174; $p=0.050$ ). In contrast, milk consumption was associated with a $43 \%$ reduction in POR for abnormal growth (POR 0.573, 95\%; CI: 0.337, 0.976; $p=0.040$ ). After adjustment for age, the mean (standard error of mean, SE) values for blood Pb were $6.22(0.50) \mu \mathrm{g} / \mathrm{dL}$ in boys and $6.72(0.49) \mu \mathrm{g} / \mathrm{dL}$ in girls of parents with an occupation in making fishing nets with lead weights. These mean blood $\mathrm{Pb}$ values were respectively 2.3 and 2.5 times higher than similarly aged boys and girls of parents with other occupations. These data are essential for setting surveillance and programmes to prevent toxic $\mathrm{Pb}$ exposure, especially in children of coastal fishing communities in southern Thailand.
\end{abstract}

Keywords: blood lead level; boatyard; childhood; lead poisoning; fishing community; lead weights

\section{Introduction}

Lead $(\mathrm{Pb})$ is an environmental toxicant that causes serious harm to child health [1,2]. Children are highly susceptible to $\mathrm{Pb}$ toxicity due to hand-to-mouth behavior, high metal absorption rates, and the nervous system that is still in developing stage [3]. Pb enters the body through ingestion and breathing. It accumulates and causes toxicity in various tissues and organs that include the liver, kidneys, blood system, central nervous system (CNS), bone, and teeth [1]. Pb toxicity in the CNS cannot be restored to normal, and the World Health Organization considers mental retardation caused by excessive $\mathrm{Pb}$ exposure as one of the most serious environmental diseases [4]. There are no reports of blood $\mathrm{Pb}$ levels that are safe for children's health. Moreover, chronic Pb exposure in childhood may predispose individuals to various diseases later in life.

Chronic exposure to $\mathrm{Pb}$ among children has been observed in various nations, including China, Brazil, Ukraine, South Africa, United States of America, and Australia [5-12]. Previous studies 
have suggested that the main reason for $\mathrm{Pb}$ exposure in children is environmentally related [5-8]. Elevation of blood $\mathrm{Pb}$ levels have been seen in children living in areas with high $\mathrm{Pb}$ contaminations, and residential areas have often been found to be a determinant of high blood $\mathrm{Pb}$ in children [6-9]. Children living near an electronic waste disposal area in China were found to have blood $\mathrm{Pb}$ levels between 4.14 to $37.78 \mu \mathrm{g} / \mathrm{dL}$ [10], while children lived near zinc and lead mining areas in Zambia had blood $\mathrm{Pb}$ levels ranging from 5.4 to $427.8 \mu \mathrm{g} / \mathrm{dL}$ [11]. In other studies, children living in fishing villages near the coast of South Africa and Tasajera (Colombian Caribbean coast) were found to have blood $\mathrm{Pb}$ levels ranging from 2.2 to $22.4 \mu \mathrm{g} / \mathrm{dL}$ and 0.4 to $50.1 \mu \mathrm{g} / \mathrm{dL}$, respectively [8,12].

Nakhon Si Thammarat Province situates in the southern part of the Gulf of Thailand, where fishing communities with mini-scale repair boatyards exist, especially in Pakpoon suburb. In the traditional boat repair method, plumboplumbic oxide $\left(\mathrm{Pb}_{3} \mathrm{O}_{4}\right)$ has been used; the strands of cotton ropes coated with $\mathrm{Pb}_{3} \mathrm{O}_{4}$ are caulked between wooden planks as waterproofing and to prevent barnacles. In one study, boat-repair workers were found to have blood $\mathrm{Pb}$ levels ranging from 9 to $89 \mu \mathrm{g} / \mathrm{dL}$, and $67 \%$ of the workers had blood $\mathrm{Pb}$ levels exceeding $40 \mu \mathrm{g} / \mathrm{dL}$, the level of concern for $\mathrm{Pb}$ exposure [13]. Other studies detected substantial amounts of $\mathrm{Pb}$ in soil and house dust from areas in close proximity to repair boatyards [14-16]. Of concern, mothers who made fishing nets with lead weights at home can introduce an additional $\mathrm{Pb}$ source to family members, especially young children who are the most vulnerable. Data of blood Pb levels in children in these communities are lacking. Hence, the present study was undertaken to assess the levels of environmental exposure to $\mathrm{Pb}$ among young children, 3-7 years of age, as reflected by blood Pb levels. We used blood Pb levels $\geq 5 \mu \mathrm{g} / \mathrm{dL}$ as a warning level, established by the U.S. Center for Disease Control [17]. In addition, we aimed to explore a range of environmental and behavioral factors, known as determinants of children's blood Pb levels from the literature reports [5-12].

\section{Materials and Methods}

\subsection{Study Design}

The present study was in compliance with ethical standards. The Office of the Human Research Ethics Committee of Walailak University approved the study protocol (approval number 58/099, approval date 24 December 2015). The study was a community-based cross-sectional design that was undertaken from January 2016 to December 2018. Children, aged 3 to 7 years, were randomly chosen from the communities in Pakpoon suburb, where traditional wooden boat repairs were commonly practiced. The Taro Yamane equation was used to calculate the sample size, with a 5\% level of significance and with a confidence coefficient of $95 \%$ [18]. The parents or guardians of all children provided written informed consent. We used structured interview questionnaires for information concerning a child's age, gender, birth weight, body weight, and height, together with children's behaviors including duration of outdoor play, home and school environment, diet, and health status.

\subsection{Collection and Analysis of Blood Samples}

The collection of children's blood samples was performed by trained nurses. Approximately $3 \mathrm{ml}$ of venous blood was collected from each child with ethylene diamine tetra-acetic acid as an anticoagulant. In preventing contamination during storage and transport, blood samples were stored at $-20{ }^{\circ} \mathrm{C}$ in a sealed compartment. Blood samples were transported to Bangkok RIA Laboratory, Thailand for an assay for blood $\mathrm{Pb}$ levels with graphite furnace atomic absorption spectrophotometry. The limit of detection is $0.03 \mu \mathrm{g} / \mathrm{dL}$.

\subsection{Assessment of Child Growth}

To assess growth of individual children, we used the standard weight for height curves for Thai children, prescribed by Thailand Ministry of Public Health [19]. Abnormal growth is defined 
as underweight or overweight using weight for height standards in accordance the Thai criteria; $>+1.5 \mathrm{SD}$ to $>+3 \mathrm{SD}$ (overweight), $-1.5 \mathrm{SD}$ to $+1.5 \mathrm{SD}$ (normal),$<-1.5 \mathrm{SD}$ to $<-2 \mathrm{SD}$ (underweight).

\subsection{Statistical Analysis}

We analyzed data with the SPSS software (SPSS Inc., Chicago, IL, USA). We examined the distributions of all continuous variables (age, body weight, height, body mass index [BMI]) for skewness. Data of the variables showing rightward skewing were presented as geometric mean \pm standard deviation (SD) values. We used age-adjusted logistic regression analysis to derive the prevalence odds ratio (POR) for high blood Pb levels $(\geq 5 \mu \mathrm{g} / \mathrm{dL}$ ) and for abnormal growth. We used the generalized linear model (GLM) analysis to derive the age-adjusted mean blood $\mathrm{Pb}$ and age-adjusted BMI. We also used GLM to evaluate an effect of parental occupation and the child's gender on blood Pb levels and BMI. $p$ values $\leq 0.05$ for two-tailed tests were assumed to identify statistical significance.

\section{Results}

\subsection{Descriptive Characteristic of Study Children}

A total of 311 children participated in the present study i.e., 160 were boys and 151 were girls. The average age was 4.67 years, ranging between 3 and 7 years (Table 1). The average body weight was $18.28 \mathrm{~kg}$, the average height was $106 \mathrm{~cm}$, and the average BMI was $16.6 \mathrm{~kg} / \mathrm{m}^{2}$. Of 311 study children, $14.8 \%$ had low birth weight and $36.7 \%$ showed abnormal growth, based on Thailand Ministry of Public Health weight for height standards [19]. The geometric mean blood Pb level was $2.81 \mu \mathrm{g} / \mathrm{dL}$, and $11.9 \%$ of children had blood Pb levels $\geq 5 \mu \mathrm{g} / \mathrm{dL}$. The highest blood Pb level was $26.40 \mu \mathrm{g} / \mathrm{dL}$, and $0.03 \mu \mathrm{g} / \mathrm{dL}$ was the lowest.

Table 1. Descriptive characteristics of study children.

\begin{tabular}{|c|c|c|c|c|}
\hline \multirow{2}{*}{ Parameters/Factors } & \multicolumn{3}{|c|}{ Study Children } & \multirow{2}{*}{$p$ Values } \\
\hline & All $(n=311)$ & Boys $(n=160)$ & Girls $(n=151)$ & \\
\hline Age (years) & $4.67 \pm 1.14$ & $4.67 \pm 1.17$ & $4.68 \pm 1.11$ & 0.776 \\
\hline Age range (years) & $3-7$ & $3-7$ & $3-7$ & - \\
\hline Body weight (kg) & $18.28 \pm 3.79$ & $18.48 \pm 4.02$ & $18.08 \pm 3.51$ & 0.332 \\
\hline Height (cm) & $106.0 \pm 8.70$ & $106.4 \pm 9.50$ & $105.6 \pm 7.80$ & 0.466 \\
\hline Body mass index $\left(\mathrm{kg} / \mathrm{m}^{2}\right)$ & $16.6 \pm 3.30$ & $16.7 \pm 3.50$ & $16.5 \pm 3.00$ & 0.540 \\
\hline Blood Pb $(\mu \mathrm{g} / \mathrm{dL})$ & $2.81 \pm 3.39$ & $2.81 \pm 3.37$ & $2.80 \pm 3.42$ & 0.947 \\
\hline Range $(\mu g / d L)$ & $0.03-26.40$ & $0.80-26.40$ & $0.03-20.40$ & - \\
\hline \multicolumn{5}{|l|}{ Prevalence rate (\%) } \\
\hline Blood $\mathrm{Pb}$ levels $\geq 5 \mu \mathrm{g} / \mathrm{dL}$ & 11.9 & 10.0 & 13.9 & 0.287 \\
\hline Birth weight $<2500 \mathrm{~g}$ & 14.8 & 12.5 & 17.2 & 0.241 \\
\hline Abnormal growth ${ }^{a}$ & 36.7 & 36.9 & 36.4 & 0.934 \\
\hline Milk consumption & 64.3 & 67.5 & 60.9 & 0.227 \\
\hline Seafood consumption & 53.7 & 51.9 & 55.6 & 0.507 \\
\hline Living near repair boatyards & 14.5 & 14.4 & 14.6 & 0.961 \\
\hline Parent occupation of producing fishing nets & 23.5 & 22.5 & 24.5 & 0.677 \\
\hline
\end{tabular}

Data for continuous variables are geometric means \pm standard deviation (SD) values. ${ }^{a}$ Abnormal growth is defined as underweight or overweight, based on the weight for height standard for Thai children; > +1.5 to > +3 SD (overweight), $-1.5 \mathrm{SD}$ to $+1.5 \mathrm{SD}$ (normal), $<-1.5 \mathrm{SD}$ to $<-2 \mathrm{SD}$ (underweight) (Nutrition Division Ministry of Public Health Thailand, 1999) [19]. $p$ values $\leq 0.05$ identify statistically significant differences between boys and girls. The Mann-Whitney U test was used to determine mean differences between boys and girls. The Chi-Square test was used to determine \% differences between boy and girls.

The environmental and behavioral data showed that $14.5 \%$ of children lived near repair boatyards, whereas $23.5 \%$ had parents with an occupation in producing fishing nets at home. More than half of children consumed milk (64.3\%) and seafoods (53.7\%). There were no statistically significant differences between boys and girls with respect to all parameters/factors considered. 


\subsection{Predictors of Blood Lead Levels $\geq 5 \mu \mathrm{g} / \mathrm{dL}$}

To screen for potential risk factors for high blood Pb levels in study children, we used age-adjusted logistic regression analysis. Table 2 presents the results of a final model that incorporated ten independent variables: gender, milk consumption, seafood consumption, signs of $\mathrm{Pb}$ toxicity, painted toys, use of painted ceramics, peeling of paint chips, living near a repair boatyard, and parent occupation. Of these ten incorporated variables, only two variables, namely parental occupation and milk consumption, were associated with the prevalence odds ratio (POR) for high blood $\mathrm{Pb}$. Parental occupation in producing fishing cast nets with lead weights was associated with 17.54 (95\%; CI: 7.093, 43.39) fold increase in POR for blood Pb levels $\geq 5 \mu \mathrm{g} / \mathrm{dL}$, compared with all other occupations $(p<0.001)$. In contrast, a child's milk consumption was associated with $61 \%$ reduction in the risk of having high blood $\mathrm{Pb}$ levels (POR $=0.393,95 \%$; CI: 0.166, 0.931; $p=0.034$ ).

Table 2. Predictors of blood lead levels $\geq 5 \mu \mathrm{g} / \mathrm{dL}$.

\begin{tabular}{cccccc}
\hline \multirow{2}{*}{ Independent Variables/Factors } & \multicolumn{4}{c}{ Blood Pb Levels $\geq \mathbf{5 \mu g} / \mathbf{d L}$} \\
\cline { 2 - 4 } & $\boldsymbol{\beta}$ Coefficients (SE) & POR & \multicolumn{2}{c}{$\mathbf{9 5 \%}$ CI } & $\boldsymbol{p}$ Value \\
\cline { 3 - 5 } & & & Lower & Upper & \\
\hline Age (years) & $-0.154(0.194)$ & 0.857 & 0.586 & 1.255 & 0.429 \\
Gender (boy = 1, girl = 2) & $0.470(0.426)$ & 1.599 & 0.694 & 3.685 & 0.270 \\
Milk consumption & $-0.934(0.440)$ & 0.393 & 0.166 & 0.931 & $0.034^{*}$ \\
Seafood consumption & $-0.101(0.436)$ & 0.904 & 0.385 & 2.124 & 0.817 \\
Symptoms of Pb toxicity & $0.490(0.431)$ & 1.632 & 0.701 & 3.799 & 0.256 \\
Painted toys & $0.351(0.459)$ & 1.420 & 0.578 & 3.489 & 0.444 \\
Use of painted ceramics & $0.081(0.508)$ & 1.085 & 0.400 & 2.938 & 0.873 \\
Peeling of paint chips & $0.279(0.498)$ & 1.322 & 0.498 & 3.504 & 0.575 \\
Living near repair boatyard & $0.093(0.581)$ & 1.098 & 0.352 & 3.428 & 0.872 \\
Parent occupation of fishing net production & $2.865(0.462)$ & 17.54 & 7.093 & 43.39 & $<0.001$ * \\
\hline
\end{tabular}

$\mathrm{POR}=$ Prevalence odds ratio. High blood $\mathrm{Pb}$ is defined as blood Pb levels $\geq 5 \mu \mathrm{g} / \mathrm{dL}$. The POR for high blood $\mathrm{Pb}$ was derived from logistic regression in which high blood $\mathrm{Pb}$ was a categorical dependent variable. Independent variables were listed in the first column. ${ }^{*} p \leq 0.05$ identify the variable as a significant risk factor or predictor for high blood $\mathrm{Pb}$ levels.

\subsection{Predictors of Abnormal Growth}

We used also age-adjusted logistic regression to determine potential effects of high blood $\mathrm{Pb}$ levels on children's growth, defined as overweight or underweight in accordance with weight and height standards for Thai children. Table 3 presents the results of such analysis that incorporated seven independent categorical variables, including high blood $\mathrm{Pb}$, milk and seafood consumptions, use of painted ceramics, living near a repair boatyard, and playing with painted toys. High blood $\mathrm{Pb}$ was associated with 2.042 (95\%; CI: 0.999, 4.174) fold increase in POR for abnormal growth $(p=0.050)$. Seafood consumption was associated with 1.713 (95\%; CI: 1.037, 2.831) fold increase in POR for abnormal growth $(p=0.036)$. In contrast, milk consumption was associated with $43 \%$ reduction in the risk of having abnormal growth (POR 0.573, 95\%; CI: 0.337, 0.976; $p=0.040$ ).

Table 3. Predictors of abnormal growth.

\begin{tabular}{cccccc}
\hline & \multicolumn{4}{c}{ Abnormal Growth $^{\text {a }}$} \\
\cline { 2 - 4 } Independent Variables/Factors & \multirow{2}{*}{$\boldsymbol{\beta}$ Coefficients (SE) } & POR & \multicolumn{2}{c}{$\mathbf{9 5 \%}$ CI } & \multirow{2}{*}{$p$ Value } \\
\cline { 4 - 5 } & & & Lower & Upper & \\
\hline Age (years) & $-0.084(0.113)$ & 0.920 & 0.737 & 1.148 & 0.459 \\
Gender (boy = 1, girl =2) & $-0.116(0.245)$ & 0.891 & 0.551 & 1.440 & 0.637 \\
Blood Pb levels $\geq 5 \mu \mathrm{g} / \mathrm{dL}$ & $0.714(0.365)$ & 2.042 & 0.999 & 4.174 & $0.050^{*}$ \\
Milk consumption & $-0.556(0.271)$ & 0.573 & 0.337 & 0.976 & $0.040^{*}$ \\
Seafood consumption & $0.538(0.256)$ & 1.713 & 1.037 & 2.831 & $0.036^{*}$ \\
\hline
\end{tabular}


Table 3. Cont.

\begin{tabular}{cccccc}
\hline & \multicolumn{4}{c}{ Abnormal Growth ${ }^{\text {a }}$} \\
\cline { 2 - 4 } Independent Variables/Factors & \multirow{2}{*}{$\boldsymbol{\beta}$ Coefficients (SE) } & POR & \multicolumn{2}{c}{ 95\% CI } & \multirow{2}{*}{$\boldsymbol{p}$ Value } \\
\cline { 2 - 5 } & & & Lower & Upper & \\
\hline Use of painted ceramics & $-0.552(0.314)$ & 0.576 & 0.311 & 1.066 & 0.079 \\
Living near repair boatyards & $0.561(0.364)$ & 1.753 & 0.860 & 3.574 & 0.123 \\
Painted toys & $0.277(0.257)$ & 1.319 & 0.798 & 2.181 & 0.281 \\
\hline
\end{tabular}

POR $=$ Prevalence odds ratio. ${ }^{\text {a }}$ Abnormal growth is defined as underweight or overweight, based on weight for height standard for Thai children; $>+1.5 \mathrm{SD}$ to $>+3 \mathrm{SD}$ (overweight), $-1.5 \mathrm{SD}$ to $+1.5 \mathrm{SD}$. (normal),$<-1.5 \mathrm{SD}$ to $<-2$ SD (underweight) (Nutrition Division Ministry of Public Health Thailand, 1999) [19]. * $p \leq 0.5$ identify significant associations between abnormal growth and variables/factors listed in the first column.

\subsection{Effect-Size Estimate}

We next used generalized linear model (GLM) analysis to quantify effects of parental occupation on blood $\mathrm{Pb}$ levels and body mass index (BMI) of children. Figure 1A shows blood Pb levels in boys and girls of parents with and without an occupation in producing fishing nets with lead weights. Age-adjusted mean $\pm \mathrm{SE}$ values for blood $\mathrm{Pb}$ in boys and girls of parents with the occupation of making fishing nets of $6.22 \pm 0.50$ and $6.72 \pm 0.49 \mu \mathrm{g} / \mathrm{dL}$ were respectively 2.3 and 2.5 times higher than the same age-adjusted mean \pm SE in boys (2.67 \pm 0.27$)$ and girls $(2.68 \pm 0.28)$ of parents with other occupations $(p<0.001$ for boys and girls, Bonferroni test).

A

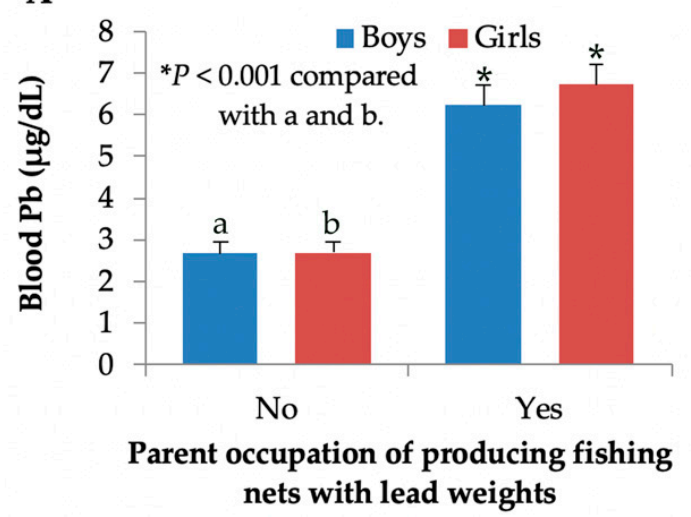

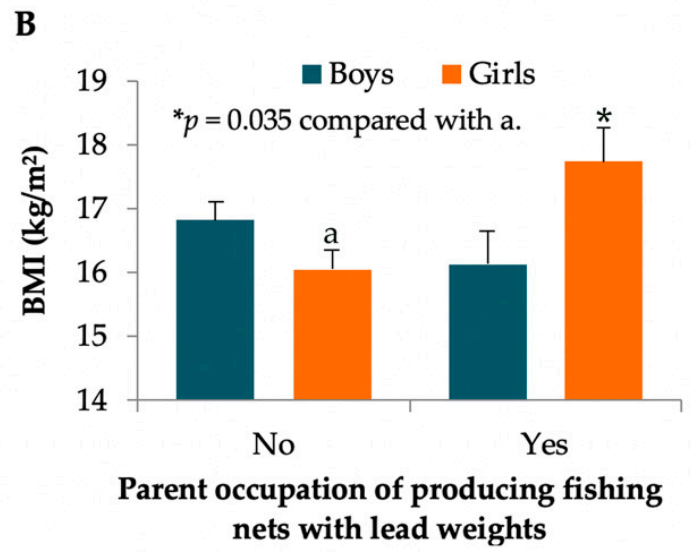

B

Figure 1. Blood $\mathrm{Pb}$ levels and BMI stratified by gender and parent occupation. Bars in (A) represent age-adjusted mean \pm standard error of mean (SE) for blood Pb levels, while bars in (B) represent age-adjusted $\mathrm{BMI} \pm \mathrm{SE}$ in boys and girls from parents with and without an occupation of producing fishing nets with lead weights. ${ }^{*} p$ values $\leq 0.05$ identify statistical significance.

Of interest, Figure 1B indicated an effect of parental occupation on BMI in girls only. Age-adjusted mean \pm SE values for BMI were $17.74 \pm 0.53 \mathrm{~kg} / \mathrm{m}^{2}$ in girls of parents with the occupation of producing fishing nets and $16.12 \pm 0.54 \mathrm{~kg} / \mathrm{m}^{2}$ in girls of parents with occupations other than making fishing nets $(p<0.035$, Bonferroni test). On average, girls of parents with the occupation of producing fishing nets had a $9.1 \%$ higher BMI than the girls of parents of other occupations.

\section{Discussion}

In the present study, we examined environmental exposure to $\mathrm{Pb}$ among 3-7 years old children, living in Pakpoon suburb, Nakhon Si Thammarat Province. The study children were randomly selected from a fishing community, where repair boatyards were located (Figure 2). The results showed that blood $\mathrm{Pb}$ levels ranged from 0.03 to $26.40 \mu \mathrm{g} / \mathrm{dL}$. Although the average blood Pb level of $2.81 \mu \mathrm{g} / \mathrm{dL}$ was below the level of concern of $\geq 5 \mu \mathrm{g} / \mathrm{dL}$, set by the CDC [17], $11.9 \%$ of children had elevated blood 
$\mathrm{Pb}$ levels $\geq 5 \mu \mathrm{g} / \mathrm{dL}$. The blood $\mathrm{Pb}$ levels recorded for children in the present study appeared to be lower than the levels found in children living in fishing communities in the Tasajera and South Africa. Blood Pb levels in children in Tasajera, Colombian Caribbean coast, ranged from 0.4 to $50.1 \mu \mathrm{g} / \mathrm{dL}$ with $57.1 \%$ of study children having blood Pb levels $\geq 5 \mu \mathrm{g} / \mathrm{dL}$ [8]. Blood Pb levels in children of fishing communities in South Africa ranged from 2.2 to $22.4 \mu \mathrm{g} / \mathrm{dL}$ with $74 \%$ of study children having blood $\mathrm{Pb}$ levels $>5 \mu \mathrm{g} / \mathrm{dL}$ [12]. The 4.8 and 6.2 times higher percentages of high blood $\mathrm{Pb}$ in South Africa and Tasajera study might be due to different $\mathrm{Pb}$ exposure sources. The South Africa and Tasajera studies both found that living near a lead smelting area was strongly associated with children's high blood $\mathrm{Pb}$ levels $[8,12]$. In contrast, there was no melting of $\mathrm{Pb}$ weights in the process of making fishing nets in this Thai study.
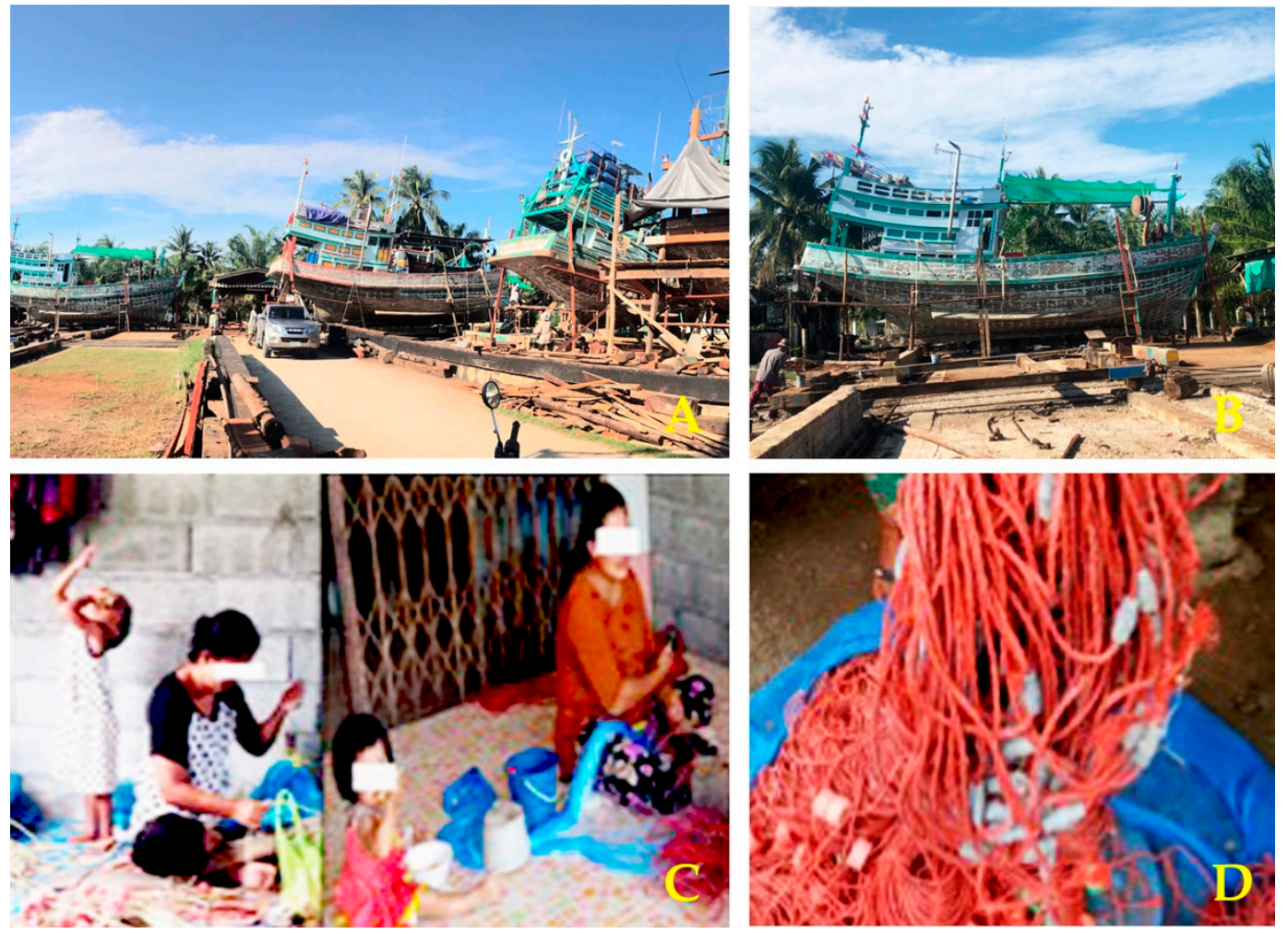

Figure 2. Boatyards, girls and working-at-home mothers, and a fishing net with lead weights. A total of 311 children were randomly selected from a fishing community in Pakpoon suburb, where repair boatyards existed (A,B). Girls were nearby while mothers were assembling lead weights to produce fishing nets (C). Approximately 180 lead weights are used to make a two-kg fishing net (D).

In the present study, we found that parent occupation involving lead weights was associated with 17.54 fold increase in risk of high blood Pb levels in children $(p<0.001)$. This might be attributable to environmental exposure via household $\mathrm{Pb}$ dust, water, and food contamination [20] from lead weights used in making fishing nets at home (Figure 2). However, living close to repair boatyards was not associated with high blood Pb levels $(p=0.872)$. Of note, blood Pb levels in both boys and girls of parents producing fishing nets were 2.3 and 2.5 times higher than similarly aged boys and girls of parents with other occupations ( $p<0.001$ for boys and girls). These data confirmed parents' occupation as a strong determinant of blood $\mathrm{Pb}$ levels. The levels of $\mathrm{Pb}$ in dust, water, and food contamination in the households that used lead weights require a further study. Blood Pb levels in mothers should also be investigated since $\mathrm{Pb}$ is readily transported through the placenta.

A child's milk consumption was associated with a $61 \%$ reduction in the risk for high blood $\mathrm{Pb}$ $(p=0.034)$ and a $43 \%$ reduction in the risk of having abnormal growth $(p=0.040)$. Milk has been reported to be a protective factor against $\mathrm{Pb}$ toxicity both in humans and experimental animals [21-24]. 
In an animal study, blood $\mathrm{Pb}$ levels decreased in lead-treated mice after nine weeks of daily milk intake. It is suggested that $\mathrm{Pb}$ absorption in gastrointestinal tract is reduced by the high calcium levels in milk, and that $\mathrm{Pb}$ absorption is enhanced by calcium deficiency [22,23]. In a longitudinal cohort study of children, aged 6-31 months [25], blood $\mathrm{Pb}$ levels were negatively correlated with calcium, magnesium, nickel, and zinc. It can be inferred that consumption of food rich in calcium and zinc can reduce $\mathrm{Pb}$ absorption. Another possible protective mechanism of milk might be due to organic substances that chelate $\mathrm{Pb}$, thereby reducing $\mathrm{Pb}$ absorption and enhancing $\mathrm{Pb}$ excretion [21]. The synergism between $\mathrm{Pb}$ exposure levels and a lack of milk consumption is unknown. The present study indicated that milk is one of the factors that reduced the risk of high blood Pb levels in children. A quantitative study on milk intake is required.

Potential adverse effects of high blood $\mathrm{Pb}$ on children's growth was observed; high blood $\mathrm{Pb}$ was associated with 2.04 fold increase in the POR for abnormal growth $(p=0.050)$, while seafood consumption was associated with a 1.71 fold increase in the POR for abnormal growth $(p=0.036)$. Likewise, blood $\mathrm{Pb}$ and seafood consumption were associated with decreased growth rates in other studies $[25,26]$. A negative effect of $\mathrm{Pb}$ on children's growth may involve disruption of the endocrine system, causing circulating levels of insulin-like growth factor 1 to fall [27]. $\mathrm{Pb}$ may affect osteoblast and osteoclast development via 1, 25-dihydroxyvitamin $\mathrm{D}_{3}$ [28,29]. Exposure to $\mathrm{Pb}$ during childhood could affect growth in adolescents and adults. This was observed in a longitudinal study in Russia, where children with blood Pb levels $\geq 5 \mu \mathrm{g} / \mathrm{dL}$ showed the most height decrease at 12-15 years of age [30]. An association between seafood consumption and abnormal growth may be attributable to methymercury in seafood [31]. Thus, children with abnormal growth rates should be monitored. Further information should be sought to identify specific types of seafood and frequencies of consumption.

Interestingly, an effect of $\mathrm{Pb}$ on $\mathrm{BMI}$ increase was seen in girls only. This is a new finding. Gender-specific neurological effects of $\mathrm{Pb}$ have been seen in prenatal and preschool age exposure conditions [32-34]. Such gender specific effects of $\mathrm{Pb}$ may be caused by gene-specific DNA methylation patterns in the brain [33]. The gender-specific difference in BMI needs confirmation. Nevertheless, the association seen between children BMI and parent occupation could be used in growth prediction and obesity prevention programs in children.

In conclusion, the present study provided baseline data on environmental $\mathrm{Pb}$ exposure levels experienced by boys and girls, aged 3-7 years together with factors associated with the high blood $\mathrm{Pb}$ levels. These data are useful in setting $\mathrm{Pb}$ surveillance and $\mathrm{Pb}$ toxicity mitigation programs for children of fishing communities. Aspects of environmental $\mathrm{Pb}$ contamination need a further investigation. $\mathrm{A} \mathrm{Pb}$ primary prevention program should be implemented in conjunction with a nutritional promotion campaign.

Author Contributions: S.Y. designed the study protocol, obtained an approval from the Office of the Human Research Ethics Committee of Walailak University, and supervised the collection of demographic data and biologic specimens; S.Y., D.W. and S.K organized and analyzed the data, created the tables and figures, and revised the manuscript.

Funding: This research was funded by National Science and Technology Development Agency (NSTDA), Ministry of Science and Technology, Thailand, grant number FDA-CO-2559-1183-74. The APC was funded by Walailak University.

Acknowledgments: This work was cooperated with by the Pakpoon Health Promoting Hospital, Pakpoon Municipality, Nakhon Si Thammarat, Thailand. We thank Steve Nazar and George Kruzynski for editing the English. We also thanks Tanaporn Khamphaya for graphic design.

Conflicts of Interest: The authors have no potential conflicts of interest to declare. 


\section{References}

1. Agency for Toxic Substances and Disease Registry (ATSDR). Toxicological Profile for Lead. ATSDR, Division of Toxicology and Environmental Medicine/Applied Toxicology Branch: Atlanta, GA, USA. 2007. Available online: http://www.atsdr.cdc.gov/ToxProfiles/tp13.pdf (accessed on 22 September 2019).

2. Cao, J.; Li, M.; Wang, Y.; Yu, G.; Yan, C. Environmental lead exposure among preschool children in Shanghai, China: Blood lead levels and risk factors. PLoS ONE 2014, 9, e113297. [CrossRef] [PubMed]

3. Jain, A.; Wolfe, L.; Jain, G. Impact of lead intoxication in children with iron deficiency anemia in lowand middle-income countries. Blood 2013, 122, 2288-2289. [CrossRef] [PubMed]

4. World Health Organization (WHO). Childhood Lead Poisoning. 2009. Available online: www.who.int/ceh/ publications/leadguidance.pdf (accessed on 30 July 2019).

5. Zhang, X.Y.; Carpenter, D.O.; Song, Y.J.; Chen, P.; Qin, Y.; Wei, N.Y.; Lin, S.C. Application of the IEUBK model for linking children's blood lead with environmental exposure in a mining site, south China. Environ. Pollut. 2017, 231, 971-978. [CrossRef] [PubMed]

6. Dong, C.; Taylor, M.P.; Zahran, S. The effect of contemporary mine emissions on children's blood lead levels. Environ. Int. 2019, 122, 91-103. [CrossRef] [PubMed]

7. Taylor, M.P.; Isley, C.F.; Glover, J. Prevalence of childhood lead poisoning and respiratory disease associated with lead smelter emissions. Environ. Int. 2019, 127, 340-352. [CrossRef] [PubMed]

8. Alvarez-Ortega, N.; Caballero-Gallardo, K.; Olivero-Verbel, J. Toxicological effects in children exposed to lead: A cross-sectional study at the Colombian Caribbean coast. Environ. Int. 2019, 130, 104809. [CrossRef]

9. Lin, S.; Wang, X.; Yu, I.T.; Tang, W.; Miao, J.; Li, J.; Wu, S.; Lin, X. Environmental lead pollution and elevated blood lead levels among children in a rural area of China. Am. J. Public Health 2011, 101, 834-841. [CrossRef]

10. Zheng, L.; Wu, K.; Li, Y.; Qi, Z.; Han, D.; Zhang, B.; Gu, C.; Chen, G.; Liu, J.; Chen, S.; et al. Blood lead and cadmium levels and relevant factors among children from an e-waste recycling town in China. Environ. Res. 2008, 108, 15-20. [CrossRef]

11. Yabe, J.; Nakayama, S.M.M.; Ikenaka, Y.; Yohannes, Y.B.; Bortey-Sam, N.; Oroszlany, B.; Muzandu, K.; Choongo, K.; Kabalo, A.N.; Ntapisha, J.; et al. Lead poisoning in children from townships in the vicinity of a lead-zinc mine in Kabwe, Zambia. Chemosphere 2015, 119, 941-947. [CrossRef]

12. Mathee, A.; Khan, T.; Naicker, N.; Kootbodien, T.; Naidoo, S.; Becker, P. Lead exposure in young school children in South African subsistence fishing communities. Environ. Res. 2013, 126, 179-183. [CrossRef]

13. Thanapop, C.; Geater, A.F.; Robson, M.G.; Phakthongsuk, P.; Viroonudomphol, D. Exposure to lead among boatyard workers in southern Thailand. J. Occup. Health 2007, 49, 345-352. [CrossRef] [PubMed]

14. Thanapop, C.; Geater, A.F.; Robson, M.G.; Phakthongsuk, P. Elevated lead contamination in boat-caulkers' homes in southern Thailand. Int. J. Occup. Environ. Health 2009, 15, 282-290. [CrossRef] [PubMed]

15. Maharachpong, N.; Geater, A.; Chongsuvivatwong, V. Environmental and childhood lead contamination in the proximity of boat-repair yards in southern Thailand-I: Pattern and factors related to soil and household dust lead levels. Environ. Res. 2006, 101, 294-303. [CrossRef]

16. Untimanon, O.; Geater, A.; Chongsuvivatwong, V.; Saetia, W.; Utapan, S. Skin Lead Contamination of Family Members of Boat-caulkers in Southern Thailand. Ind. Health 2011, 49, 37-46. [CrossRef] [PubMed]

17. Centers for Disease Control and Prevention (CDC). Childhood Lead Poisoning Prevention Program. 2019. Available online: https://www.cdc.gov/nceh/lead/default.htm (accessed on 30 July 2019).

18. Yamane, Taro. Statistics: An Introductory Analysis, 2nd ed.; Harper and Row Publication: New York, NY, USA, 1973; Available online: https://www.gbv.de/dms/zbw/252560191.pdf (accessed on 25 January 2015).

19. Nutrition Division, Department of Health, Ministry of Public Health. The Reference Guide for the Assessment of Weight and Height Growth of Thai Children Aged 1 Day-19 Years Old; Ministry of Public Health: Nonthaburi, Thailand, 1999.

20. Chambial, S.; Shukla, K.K.; Dwivedi, S.; Bhardwaj, P.; Sharma, P. Blood Lead Level (BLL) in the Adult Population of Jodhpur: A Pilot Study. Indian J. Clin. Biochem. 2015, 30, 357-359. [CrossRef] [PubMed]

21. Zhang, Y.; Li, Q.; Liu, X.; Zhu, H.; Song, A.; Jiao, J. Antioxidant and micronutrient-rich milk formula reduces lead poisoning and related oxidative damage in lead-exposed mice. Food Chem. Toxicol. 2013, 57, 201-208. [CrossRef] [PubMed]

22. Kordas, K. The "Lead Diet": Can Dietary Approaches Prevent or Treat Lead Exposure? J. Pediatr. 2017, 185, 224-231. [CrossRef] 
23. Kordas, K.; Casavantes, K.M.; Mendoza, C.; Lopez, P.; Ronquillo, D.; Rosado, J.L.; Vargas, G.G.; Stoltzfus, R.J. The association between lead and micronutrient status, and children's sleep, classroom behavior, and activity. Arch. Environ. Occup. Health 2007, 62, 105-112. [CrossRef]

24. Gulson, B.; Mizon, K.; Taylor, A.; Wu, M. Dietary zinc, calcium and nickel are associated with lower childhood blood lead levels. Environ. Res. 2019, 168, 439-444. [CrossRef]

25. Little, B.B.; Spalding, S.; Walsh, B.; Keyes, D.C.; Wainer, J.; Pickens, S.; Royster, M.; Villanacci, J.; Gratton, T. Blood lead levels and growth status among African-American and Hispanic children in Dallas, Texas - 1980 and 2002: Dallas Lead Project II. Ann. Hum. Biol. 2009, 36, 331-341. [CrossRef]

26. Yang, H.; Huo, X.; Yekeen, A.T.; Zheng, Q.; Zheng, M.; Xu, X. Effects of lead and cadmium exposure from electronic waste on child physical growth. Environ. Sci. Pollut. Res. Int. 2013, 20, 4441-4447. [CrossRef] [PubMed]

27. Ronis, M.J.; Badger, T.M.; Shema, S.J.; Roberson, P.K.; Templer, L.; Ringer, D.; Thomas, P.E. Endocrine mechanisms underlying the growth effects of developmental lead exposure in the rat. J. Toxicol. Environ. Health A 1998, 54, 101-120. [PubMed]

28. Berglund, M.; Akesson, A.; Bjellerup, P.; Vahter, M. Metal-bone interactions. Toxicol. Lett. 2000, 113, $219-225$. [CrossRef]

29. Flora, G.; Gupta, D.; Tiwari, A. Toxicity of lead: A review with recent updates. Interdiscip. Toxicol. 2012, 5, 47-58. [CrossRef] [PubMed]

30. Burns, J.S.; Williams, P.L.; Lee, M.M.; Revich, B.; Sergeyev, O.; Hauser, R.; Korrick, S.A. Peripubertal blood lead levels and growth among Russian boys. Environ. Int. 2017, 106, 53-59. [CrossRef]

31. Chan, H.M. Advances in methylmercury toxicology and risk Assessment. Toxics 2019, 7, 20. [CrossRef] [PubMed]

32. Wang, J.; Gao, Z.Y.; Yan, J.; Ying, X.L.; Tong, S.L.; Yan, C.H. Sex differences in the effects of prenatal lead exposure on birth outcomes. Environ. Pollut. 2017, 225, 193-200. [CrossRef] [PubMed]

33. Singh, G.; Singh, V.; Wang, Z.; Voisin, G.; Lefebvre, F.; Navenot, J.-M.; Evans, B.; Verma, M.; Anderson, D.W.; Schneider, J.S. Effects of developmental lead exposure on the hippocampal methylome: Influences of sex and timing and level of exposure. Toxicol. Lett. 2018, 290, 63-72. [CrossRef]

34. Cecil, K.M.; Brubaker, C.J.; Adler, C.M.; Dietrich, K.N.; Altaye, M.; Egelhoff, J.C.; Wessel, S.; Elangovan, I.; Hornung, R.; Jarvis, K.; et al. Decreased brain volume in adults with childhood lead exposure. PLoS Med. 2008, 5, e112. [CrossRef] 